\title{
Transformations in Igbo Cosmology during Slavery: A Study of the Geneses of Place-Names, Totems \& Taboos
}

John N. Oriji

\section{(2) OpenEdition}

\section{Journals}

Édition électronique

URL : http://journals.openedition.org/etudesafricaines/15717

DOI : 10.4000/etudesafricaines. 15717

ISSN : 1777-5353

Éditeur

Éditions de l'EHESS

\section{Édition imprimée}

Date de publication : 8 décembre 2009

Pagination : 953-968

ISBN : 978-2-7132-2209-2

ISSN : 0008-0055

Référence électronique

John N. Oriji, «Transformations in Igbo Cosmology during Slavery: A Study of the Geneses of PlaceNames, Totems \& Taboos », Cahiers d'études africaines [En ligne], 196 | 2009, mis en ligne le 01 janvier 2011, consulté le 21 décembre 2020. URL : http://journals.openedition.org/etudesafricaines/15717 DOI : https://doi.org/10.4000/etudesafricaines.15717 


\section{Transformations in Igbo Cosmology during Slavery A Study of the Geneses of Place-Names, Totems \& Taboos*}

The Igbo area of West Africa experienced intensive slave trading activities, especially between 1680 through the 1830s. Recent studies, which indicate that about 1,34 million Igbo people were shipped to the New World between 1470 and 1867, point to the magnitude of the slave trade in the Igbo hinterland (Douglas 1977). Although the historiography of the slave trade in the Igbo region continues to grow, little is known about the religious dimensions of slavery, and the various ways that local communities responded to slave raids and wars. This essay examines how the emergence of the Aro trade network physically dislocated whole communities, and also forcibly transformed their cosmology (world view) and collective identities. It shows that some communities raided by the Abam took on new names and some of them developed totems and taboos that have continued to reinforce their common cultural consciousness ${ }^{1}$. It concludes by evaluating the roots of taboos in the light of existing anthropological theories, and also raising methodological issues that may be helpful in advancing the study of the history of the Igbo and other African peoples.

Simon Ottenberg was the first anthropologist to examine the religious dimensions of slavery in Igboland. He used the Aro oracle (Chuku, IbiniUkpabi) to illustrate the integrative roles it played in the political economy of Southeastern Nigeria between the $18^{\text {th }}$ and $19^{\text {th }}$ centuries (Ottenberg 1958). Although some of his conclusions will be questioned in this paper, Professor Ottenberg's work opened up new areas of research on Igbo cosmology and slavery that have continued to inspire Igbo specialists. For

\footnotetext{
* This paper was first presented at the First International Conference on Igbo Studies: A Tribute to Simon Ottenberg, Cornell University, Ithaca, April 4-5, 2003.

1. This study is concerned largely with community and "clan" totems and not personal totems like those associated with Chi (one's personal god), and Ikenga.
} 
example, his work helped the present writer to explore other aspects of the Aro trade system, including sections of this study dealing with the evolution of totems and taboos during Abam raids.

\section{Agrarian Igbo Cosmology and the Origins of Totems and Taboos}

The origins of totems and taboos in Igbo and other West Africa societies are unknown. But the extensive research done in other regions of the world by cultural anthropologists like C. Levi-Strauss, A. Goldenweiser, and J. G. Frazer are helpful in making some extrapolations about the roots of totems and taboos among Igbo peoples and the functions they performed in their society (Boas 1916; Levi-Strauss 1963; Leach 1967; Goldenweiser 1968). Close analysis of Igbo cosmology suggests that the origins of totems and taboos among Igbo peoples date back to the Neolithic period (500 B.C.2100 A.D.). Like other agrarian peoples, the Igbo attached much importance to land (Ala, Ana), and ritualized it. The goddess of the land, agriculture and fertility (Ala, Ani) was their most dominant deity. Although the shrine of Ala was located in the common political, cultural and commercial center of each community, the totemic emblems of the goddess were in some places, perennial trees like Uha planted at the center of each compound (Ala Ezi, lit. earth goddess of a compound), to serve as its guardian spirit and protector, and the source of its ethical ideals. Sacred Uha trees were also planted in mounds demarcating the boundaries of family and village lands, and people were forbidden to dismantle the mounds or cut down the sacred trees (Oriji 1986, 1998).

More elaborate taboos associated with the earth-deity of a community were used to sanctify its major laws during meetings of the Council of Elders (Amala, lit. home of Ala) at their common political, commercial and cultural center, and the abode of Ala (Okpu-Ala, Ama-Ukwu) (ibid.). Violations of the sacred laws of Ala were seen as taboos and were regarded as the most serious offense that an individual could commit in Igbo society (Aru, Alu). The taboos covered a wide spectrum of crimes ranging from incest to stealing farm crops. C. K. Meek's study offers an insightful analysis of the centrality of Ala in the Igbo system of jurisprudence:

"Ala is the fountain of human morality, and in consequence, a principal legal sanction. Homicide, kidnapping, poisoning, stealing, adultery [...] and all offenses against Ala must be purged by rites to her. Ala deprives evil men of their lives, and her priests are the guardian of public morality. Laws are made in her name, and by her, oaths are sworn. Ala is in fact, the unseen president of the community" (Meek 1937: 25).

The taboos of Ala were not confined only to humans, but also encompassed lower animals and other species that thrive on earth. As an example: 
"If a goat climbs on to the roof of a house, it is regarded as having committed an offense against Ala and [...] was in the olden days [killed] [...]. A cock that crows, or a hen that lays at night in an open space is killed [...]. It is ordained that a hen which hatches out a single chicken shall be deprived of its life. Similarly, a cow which bears two calves must be taken out of the community" (ibid.: 30-31).

It is noteworthy that the priest of Ala (Eze Ala) lived a mystical life, surrounding himself with elaborate taboos. According to scholars who have studied these taboos in detail, the Ezeala in the Ngwa area for example, was forbidden to eat some animals said to be unholy, including carnivorous animals, rabbits and snakes. Moreover, to ensure that his humanity was not be betrayed, the Ezeala was not allowed to eat in the presence of common people or sleep outside his temple. Similarly, he was forbidden to cut his hair in public or drink palm wine with non-titled men. It was also a taboo for the Ezeala to see corpses, cross the Imo River, and greet anybody in the morning of the four-day Igbo market week before presiding over the communal propitiation ceremony of Ala (Allen 1933).

\section{Totems and Taboos Associated with Origins of Igbo Communities}

In addition to Ala, the antiquity of totems and taboos among the Igbo is evidenced by their association with the origins of some communities. A typical example is the community of Nvosi in Isiala Ngwa which numbers over 150,000 people, and traces its ancestry to one Avosi, named after the sacred Avosi tree. Explaining the etymology of Avosi, some informants claim that when their ancestor was born, he was afflicted with an illness that nearly took his life. His parents consulted a native doctor who quickly cured the young boy by giving him an herbal medication prepared from the Avosi tree. The parents were overjoyed and named their son Avosi in honor of that tree. Among Ndi Nvosi, the Avosi tree is a sacred object associated with many taboos. It is not to be cut down or used as firewood. It is also a taboo to strike an Nvosi person with an object made of an Avosi tree. The tree is planted around sacred shrines to symbolize the spirit of the ancestors ${ }^{2}$.

\section{The Njaba of Orlu and the Python River Totem (Eke)}

Unlike the Nvosi, the Njaba of Orlu provide us with an example of totems and taboos whose roots are closely linked with their habitat. They live around the Njaba river, which is central to their survival. Their agricultural life-cycle depends on the river, and it serves as a major source of drinking

2. The present writer documented information on Nvosi origins during field work in 1975, and 1981-1982. 
water, fishes, crabs and other aquatic animals that are rich in protein. More importantly, the Njaba is home to the sacred python (Eke), which is believed to represent the founding father of the community. Pythons are deeply revered in the community, and they move about freely. Nobody molests or kills them, and their appearance is often regarded as ominous. They may, for example, communicate important messages from the ancestors to individuals and save them from calamities. The religious and psychological importance some Igbo communities attach to the python is further evidenced by Chinua Achebe's novel, Things Fall Apart, which described the crisis that erupted in the Umuofia clan when fanatic Christians like Enoch killed the sacred python that represented the ancestors of the clan (Achebe 1966).

\section{The Lagwa Okwata Community of Mbaise and the Monkey (Enwe) Totem}

Like the Njaba, the Lagwa of Mbaise live in an area that was once densely forested. Their livelihood was closely interwoven with the rain forest and its plants and animals. As in many other parts of Igboland, increased population pressure and deforestation have contributed to the extinction of many tropical plants and animals in Lagwa. The major animal that continues to thrive in abundance in Lagwa community is the monkey. The survival of the monkey and its adoption as a totem is probably due to its mysterious resemblance to humans. The Lagwa may have also been impressed by its intelligence, and perceived ability to communicate with humans and their ancestors. Monkeys continue to roam about freely in Lagwa, and when they enter houses, people show much reverence to them, offering food, water and libations to their august visitors ${ }^{3}$.

The Ikem Osokwa Nvosi Community and the Totem of the BushFowl (Okwa)

According to a tradition recorded by J. G. C. Allen, three brothers, Umuka, Ikem and Obika, lived peacefully at the Obikiabia village of Ngwaukwu (named after Obika) until a dispute broke out among them. During the dispute, Umuka and Ikem allied against Obika, and chased him out of his home. Angered, Obika is said to have hired a band of local warriors to regain his home, and decisively defeat his opponents. Luckily, the two brothers got wind of the invasion, and quickly fled through the bush with their family southwards to the Nvosi area. But as the two brothers fled, they:

3. Information on the Lagwa monkey totem was obtained from Rita Oriji on May 2, 2000. While in high school, Rita spent part of her holidays at Lagwa with her classmates who hailed from that town. 
"Overlooked the fact that [their] footprints were clearly visible in the sandy soil, and [their] concealment would have been in vain had it not been for the fact that, just before Obika and his warriors reached the spot, a bush fowl (Okwa), passed along the path, obliterating the path of the refugees. In gratitude for what was regarded as a divine intervention, Umuka vowed that he and his descendants would treat the bush-fowl as sacred. From that time up till the present day, his descendants have carefully observed this taboo, and in memory of this chapter of their history have taken the name Osokwa (lit. bush-fowl is forbidden)" (Allen 1933: 79) ${ }^{4}$.

The population of the Osokwa Nvosi community has grown to over 20,000 people. It is also noteworthy that when Umuka migrated with his family southwards to found the large community of Akpa Osokwa in Osisioma Ngwa Local Government Area, they preserved the totem of the bush-fowl in their culture. Similarly, other offshoot settlements of Osokwa that do not kill or eat the bush fowl include the Akpa Osokwa community south of Aba and the Osokwa community in Nsukka.

\section{The Nnewi and the Totem of the Rabbit (Ewi)}

The Nnewi example, documented by a local historian, is similar to that of Osokwa. According to a variant of its traditions, the etymology of Nnewi is derived from the critical role a rabbit played during a threatened invasion of the town. To abort the invasion:

"A [native] doctor was summoned to prepare a charm which at night, transformed itself into a rabbit (Ewi) that covered the entire fringes of Nnewi with its footprints. When at last, the individual invaders drew near, they saw these footprints and concluded that [nobody lived in the area]. Thenceforth, they retreated and the invasion fizzled out. Thus, Nnewi became safe and, in commemoration of this [event], the town was given the name, Nnewi by its inhabitants" (Alutu 1985; Oriji 1994: 50).

Although traditions do not indicate who the invaders were, it is noteworthy that the Nnewi were involved in protracted disputes with their neighbors and members of the Anaedo/Agbaja clan (comprising Oraifite, Isu and Ichi) until recent times. The totem of the rabbit still thrives in their community, and it is a taboo for people kill and eat the animal.

\section{Slavery and the Evolution of Totems and Taboos: The Theory of Social Violence}

The Establishment of the Aro Trade Network: The Aro Oracle, Ekpe/Okonko Society and Abam Warriors

More than any institution in Igbo history, slavery provides the clearest evidence of the linkages between violence and the origins of totems and taboos.

4. See also J. N. ORIJI (1994: 162, 1998: 18). 
To better understand the genesis of new totems and taboos during slavery, it is necessary to divide this section of the study into two parts. The first part deals with the Aro oracle (Chukwu), showing how it contributed to changing Igbo cosmology, while the second part discusses Abam raids and the evolution of new totems and taboos in various communities.

The symbiotic relationships that existed between the Aro, the dominant slave traders of the hinterland, and their Abam warriors need not concern us here since many researchers have already studied them (Uka 1972; Oriji 1986). Nonetheless, it is necessary to point out that the establishment of the Aro trade network contributed to immense changes in Igbo cosmology. Chuku, the high God of the Igbo pantheon, is believed to live in heaven and was worshipped through the intermediary of other gods. In fact, before slavery, it is likely that many Igbo communities did not have any shrines of the high God. But when the Aro began to expand their trade network in the hinterland, they claimed to be agents of Chukwu, and helped to establish his shrines (Ihu Chukwu) in many communities ${ }^{5}$.

The Aro increased their popularity through these claims, since Chukwu was said to be the author of all blessings including fertility, good health and prosperity. Individuals who could not afford to travel to Arochukwu to consult the oracle would be obliged to offer sacrifices to Chukwu in their local shrines. In addition to the local priests of Chuku, the Aro propagated the Ekpe/Okonko society in Southern Igboland, using its leading members and multi-title holders as an arm of their trade network. Local Okonko members provided hospitality, slaves and other commodities to itinerant Aro traders in exchange for foreign goods like cloth, tobacco, and gin. As the title men of Ekpe/Okonko became increasingly influential and powerful, they began, in the words of J. G. C. Allen, "to take over many duties which hitherto had been regarded as the prerogative of the [Ezeala] and Amala" (Allen 1933: 41), using their dreaded organization of masked men to ruthlessly enforce customary laws. R. Stevenson (1968: 227) rightly argued that "the very process of Aro domination involved a divide and rule policy which kept local units fragmented". On one hand were the Aro and their local devotees and multi-title holders of Ekpe/Okonko, and on the other hand were the Ezeala and Amala who resisted the new centers of power that were undermining their authority.

Elizabeth Isichei (1976: 105) arrived at similar conclusions in her study of Northern Igbo communities regarding the towering role that the Ogaranya and titled men who were associated with the Aro trade network played in the political and judicial affairs of their community. For example, they made laws, arbitrated disputes, and took decisions that affected their community. Due to the threat they posed to traditional authority holders, Isichei

5. In some communities, the priests of Chukwu were Aro, but in others, the Aro charged fees to individuals to consecrate Ihu Chukwu for them. 
concluded that the $19^{\text {th }}$ century was: "A time of changing political forms when the rule of elders was undermined by the rule of the wealthy and powerful."

\section{The Abam Raids: Change of Place-Names, and Emergence of Totems and Taboos}

The conflicts in Igbo society were further exacerbated by the Abam raids. Some of the communities that were raided took on new names and developed totems and taboos to honor the spiritual forces that were believed to have saved them during the incursions. Examples from two communities in the Ngwa area are enlightening: it concerns the Ntigha Uzo/Okporo Ahaba Community of Isiala-South Local Government and the genesis of the Plantain Totem. According to oral traditions, before the genesis of the Aro oracular trade, Ntigha-Uzo, a community that now numbers over 30,000 people, had developed, a large market in their cultural capital, Umu Ajuju, which was also the abode of their common earth-deity. Due to the strategic location of the community in Owerrinta area, its central market attracted not only neighboring Ngwa communities, but other Igbo people from Etche, Okpala, Owerri and Mbaise axis, and some regional traders as far flung as the Annang/Ibibio area. The Aro began to infiltrate into the area during the period of the slave trade, hoping to colonize it. Their infiltration probably began from a nearby community of Aro Ngwa where they had settled in two waves (Allen 1933: 80-81; Oriji 1998: 43-45). Two brothers, Okachi and Ngiri from the Umu Nka (Umu Nkita) quarter of Arochukwu, who claimed that they were refugees displaced by floods from their homeland supposedly led the first wave of Aro settlers into the area. The elders of the present day Umu Nwaro village of Aro Ngwa were said to have shown hospitality to the refugees and offered them food and land to settle. The next wave of Aro settlers who arrived in Umu Nwaro appear to have been larger in number. They were from the Obi Ekwensu quarter and were led by one Okarafor who came with his slave called Ukpabi. As their population increased, the Aro recruited Abam soldiers to invade the cultural center of Ntigha Uzo and nearby villages (ibid.).

The Abam swoop is said to have taken place in the early morning hours when people were asleep. During the confusion, some of the villagers were killed by the Abam, while the Aro captured many others for enslavement. But a majority of the people miraculously escaped. Among those who escaped by hiding themselves in a grove of plantain trees was one Esu, the priest of Ala, and the spiritual head of the community. Consequently, Ntigha Uzo people recognized the plantain tree as a sacred object for protecting their priest and other escapees. They, and others from their offshoot settlements neither eat plantains nor cut down its trees. Because of these taboos, Ntigha Uzo people are still known by their Ngwa neighbours as Ndi Oso Abirikia (lit. Those who do not eat plantains) (Allen 1933: 81). 
It is also significant that a large lineage group of Ntigha Uzo acquired a new name after the Abam raids. The head of the lineage group is said to have hidden himself in his wife's chicken pen (Nkpuka) during the raids. The group has developed into the large village known at the present time as Nkpuka (lit. chicken pen).

Abam Raids in Ohia-Ukwu, Ohanze and the Development of the Totem of the Three-Leaved Yam (Onu).

\section{The Ngboko and their Totem of the Three-leaved Yam (Onu)}

The Ngboko of eastern Ngwaland, who were famous itinerant traditional healers and diviners, have a similar tradition associated with Abam raids. According to this tradition, before slavery, the Ngboko Ohanze capital of Ohia-Ukwu was a major commercial center that attracted traders from neighboring Ngwa, Ukwa, (Asa and Ndokki) and Annang/Ibibio communities. Aro traders were naturally attracted to the strategic commercial center of Ohia-Ukwu during slavery. They thought of colonizing Ohia-Ukwu to use it as a major depot linking them from the Bende area to eastern Ngwlaland and Ukwa, and the termini of the trade route in the eastern Niger Delta (Oriji 1998: 43-45).

It is likely that the Ngboko resented the growing presence of the Aro in Ohia-Ukwu, which, they reasoned, undermined their political and commercial interests, and increased social violence in their community. As tensions grew, the Aro enlisted Abam mercenaries to raid Ohia-ukwu. In a sudden swoop at dawn, the Abam invaded the town and nearby communities, enslaving and killing a large number of people. As in Ntigha-Uzo, the priest of the Uju deity is said to have mysteriously escaped during the invasion, hiding himself under the cover of the three-leaved yam (Onu). Since this incident, the Ngboko are believed to have adopted the threeleaved yam as their totem. Much reverence is accorded to the crop, and it is a taboo for anyone to destroy it or eat its root (Allen 1933: 81).

Ngboko traditions also provide some evidence of another taboo that emerged during the Abam raid. According to the traditions, a dog is believed to have nearly betrayed the priest of Uju by barking incessantly near the place he was hiding during the raid. The Ngboko extended their taboos to the dog, which is seen as a perfidious and pernicious animal. Their taboos prohibit, till the present time, any indigene of Ngboko from rearing a $\operatorname{dog}^{6}$.

6. It is interesting to note that at the end of the Nigerian civil war in 1970, an Umuahia trader who is said to have carried his dogs on a bicycle to sell at Aba market stopped briefly at the Ngboko area without knowing about their taboos on dogs. The Ngboko chased the trader away after killing some of his dogs. 
Abam invasions are still remembered as the most violent events that changed the history of Ntigha Uzo and Ohanze during slavery. Admittedly, the demographic and economic impacts of the invasions fall outside the purview of this research. But it is likely that the number of people who died in Ntigha Uzo was considerably high, and Allen may have been close to the truth when he described the raid on the community as a "massacre" (ibid.). As for those who survived, they adapted in varying ways to the demands of their "new world". Many who felt insecure and could not withstand the psychological shock of the invasions, migrated to nearby communities. Ntigha Uzo emigrants for example, fled to Ngwa Obi, Amaise, Amavo and Amasa, while those of Ohanze dispersed to Ngboko-Amiri, Ndiakata and Ibeme.

A majority of the population that chose not to migrate rebuilt itself spiritually and physically. The mysterious escape of their priests reinforced their faith in Ala, and especially in the ancestors who protected them during the invasions. They incorporated new totems of the ancestors in their cosmology that embodies their historical experiences during slavery.

It is noteworthy that the invasions are said to have aroused a deep sense of military alertness among the Ngwa. People began to take various security measures to protect themselves from Abam raids. Young men, for instance, were mobilized to police their communities, and war-gods like Ike-Oha and Udu-agha were consecrated to drill the younger generation in the art of self-defense. Hunters and local warriors searched their villages for the Abam and other suspicious faces, and women carried out economic activities in groups to avoid being kidnapped (Oriji 1998: 43-45). Major A. G. Leonard (1898: 190), an adventurous British military intelligence officer who visited parts of Ngwaland in the late $19^{\text {th }}$ century, has given a vivid account of what he saw:

"Although the people [the Ngwa] who enroute turned out in thousands to look at us, appeared to be very friendly and peaceably disposed, not a man apparently moved a step without carrying a naked sword in one hand and a rifle at full cock in the other. Even the boys [...] some of them not higher than an ordinary man's knee [...] walked about armed with bows, and pointed arrows made out of reeds."

The alertness of the Ngwa helped to prevent further Abam raids in their communities. The Aro also realized that trade and warfare were contradictory institutions. The increasing hostility they encountered in Ngwaland convinced them to search for more peaceful ways of conducting trade. The Aro then began to propagate the Ekpe/Okonko/Ekpe which as already noted, was an important arm of their trade network in the Ngwa area and other parts of Southern Igboland (Oriji 1998: 45-50). 


\section{Raids without Totems: The Ebiri/Igboerughi/Igbere Example}

Although examples from Ngwaland and other places link the roots of totems with slave raids, there were cases where the raids only led to changes in the names of towns, as illustrated by the Ebiri of Southeastern Igboland. According to its local historians, the original name of the town known as Igbere at the present time was Ebiri. But during slavery, the Aro known in local parlance as Aro Oke-Igbo invaded the town with their Abam warriors. The Ebiri, who probably anticipated the invasion, were able to vanquish the intruders after a protracted battle. The courage that the Ebiri displayed led them to proudly call themselves "Igbo Erughi" (lit. the town the Aro could not reach/capture), a name which was anglicized as Igbere during colonialism (Ukaegbu 1974: 13; Oriji 1994: 182). The Igbere people still respond emotionally to this history, as in recent times when an Igbere elder, during a public ceremony, saluted his townsmen thus: Igbo Erughi Kwenu, to which they responded with a thunderous applause.

\section{Genesis of the Umuchu Confederacy}

Oral traditions also indicate that small and independent communities that lacked the resources to defend themselves against the Abam allied with their neighbors for their mutual defense. Typical examples are Ihite, Ogwugwu and Okpu-na-Achala that are said to have engaged the services of a diviner to cement their alliance, and ward off possible Abam raids with his medicine called "Ichu" (lit. prevention, driving away). The community then derived its name, Umuchu (lit. children of Ichu) from the medicine. Oral traditions claim further that the diviner buried symbols of Ichu in the common Nkwo market of the confederacy and in the Odere Lake, respectively known as Nkwo Ichu and Odere Ichu till the present day (Mojekwu 1984: 3).

\section{Theoretical Issues: Roots of Totems and Taboos, and their Varying Interpretations}

The Igbo example suggests that no single theory can be used to explain the origins and functions of totems and taboos in human history. As Igbo society changed, its cosmology and the totems associated with them also changed. During agriculture, for example, the religious and politico-judicial functions that totems and taboos associated with them served, reached their apogee as evidenced by Ala-ezi, and Ala. The functional roles that totems roles played in society are further evidenced by the medicinal value of the Avosi tree, and the python and monkey totems of the Njaba and Lagwa respectively, meant to help the communities to influence spiritual forces they believed were the sources of fertility and other blessings. The foregoing examples validate anthropological theories that seek to explain the genesis 
of totems in the context of the human quest for guardian spirits that would help them to control their physical and cosmological world.

The roots of totems and their functions, however, appear to have undergone some changes during civil wars and slavery. Totems that were seen as protectors and benefactors evolved during social violence, and were not freely chosen by the people as evidenced by the examples of Ikem Nvosi, Nnewi, Ntigha Uzo and Ohia Ukwu Ohanze. Depending on how one looks at the impact of slavery, it might be argued, at least, from the perspective of the slave traders, that totems and taboos owe their origins to economic forces, and the quest, say by the Aro, to spread the religious influence of their oracle in Igboland. One can also include in this multi-faceted theory, the Abam whose motives were largely dictated by the search for social validation within their communities, and thus by their zeal to climb the social ladder and become an Ufiem (Hero). However, if we turn to the victims of the raids in whose communities the totems and taboos originated, the earlier theory which links their roots to violence and its aftermath offers a more plausible explanation to a problematic issue.

It is also significant that the names of some communities changed due primarily to the totems and taboos that developed during slavery. For example, Ikem Nvosi and its offshoot settlements are called Osokwa, Ntigha Uzo is known as Oso Abirika, the Ebiri (Igbere) called themselves Igbo Erughi, and the communities that formed the Umuchu confederacy. The names that grew out of the historical experience of the communities during slavery have continued to provide a common consciousness of shared historical identity among them till the present time.

It is tempting to theorize that these communities worship their totems because of the close religious and psychological ties that exist between them and totemic plants and animals. However, totems need to be understood in the context of the underlying animist religious philosophy of the communities. Totems are not worshipped. Instead, sacrifices are offered through totemic objects to the gods they represent.

\section{Evaluation of the Impact of the Aro Trade Network}

The Aro trade system had a contradictory impact on Igbo society. On one hand, as Simon Ottenberg (1958) correctly noted, it helped to link Igbo communities with the commercial network of Southeastern Nigeria and parts of the Middle Belt region of Nigeria. It also transformed the cosmology of many communities as evidenced by the propagation of the Aro oracle and the Ekpe/Okonko society. On the other hand, the Aro trade network, especially, the Abam invasions, and the increasing political-judicial roles the Ekpe/Okonko society and the Ogaranya and titled men played in their communities, contributed to the fragmentation of traditional moral authority of ritual figures in Igbo society. 


\section{Methodological Issues}

The present study, which discusses the place of totems and taboos in the Igbo cosmology and the changes they underwent over time, raises some fundamental questions on methodology, and the sources for studying African history. Although the structural and functionalist approach of anthropologists lacks a time perspective, yet as evidenced by this study, it is helpful for enriching historical research. It is also significant that contemporary historical inquiry is being advanced by literary and film theory among others sources. The increasing diversity of sources of history is raising a red flag among orthodox historians who think that the "new history" is undermining the philosophical foundation of the historical profession that seeks to maintain objectivity in analyzing the various dimensions of the human experience. Thus, orthodox historians are wondering if works of fiction and those dealing with totems and taboos, as well as other symbolic elements of culture, can be used as reliable sources of historical data. G. I. Jones'contribution (1988: 4-5) to the debate on Igbo oral traditions is insightful. According to Jones, totems and legendary traditions of Igbo origins are simply myths, which should be seen in their functional terms as social charters of a community meant to legitimate its existing political structure. I believe that many orthodox historians will likely share the views of Jones.

Nonetheless, as postmodernist research shows, the quest for "objectivity" in history is an illusory task since each historian interprets the so-called hard facts in varying ways depending on his/her mental images, orientation, cultural and ideological background, among other factors? ${ }^{7}$. History then has many voices that contain some elements of fiction. In addition to its epistemological crisis, we need to realize that history is not the only discipline that deals with the human experience. Literature, drama, art, philosophy and other disciplines in the arts and humanities also offer us diverse insights into the human experience. Historians need to develop new techniques of inquiry that will help to broaden the frontiers of scholarship in Igbo history. As this study has shown, totems and taboos and other socalled myths in Igbo history can be decoded to understand their historicity better. When some Igbo communities claim that their forefathers descended from some animals, we should not take their account literally and began to speculate about its mythical elements dealing with zoology and human ancestry. What we need to do as post-modern scholars is to examine these narratives more deeply, and understand when and why "myths" of this nature emerged, and how they are used to explain the collective human experience of specific societies.

California Polytechnic State University, San Luis Obispo.

7. For a critique of the "new history", see Alison SCHNEIDER (1998: 12). 


\section{BIBLIOGRAPHY}

Achebe, C.

1966 Things Fall Apart (Portsmouth: Heinemann Educational Publishers).

Allen, J. G. C.

1933 Intelligence Report on the Ngwa Clan, vol. 1 (Enugu: Nigerian National Archives 23-24).

Alutu, J. U.

1985 Nnewi History (Enugu: Fourth Dimension Press).

BOAs, F.

1916 "The Origin of Totemism", American Anthropologist 18: 319-326.

Douglas, B.

1977 “My Own Nation: Igbo Exiles in Diaspora”, in D. Eltis \& D. Richardson (eds.), Routes to Slavery: Direction, Ethnicity, and Mortality in the Transatlantic Slave Trade (London: Frank Cass): 19-23, 22-30.

Goldenweiser, A.

1968 History, Psychology, and Culture, Gloucester (Mass.: Alfred A. Knopf Press).

ISICHEI, E.

1976 A History of Igbo People (London: The Macmillan Press).

JONES, G. I.

1988 The Background of Eastern Nigerian History, vol. Oral Traditions (New Haven: HRA Flex Books, FF1/3, "Ethnographic Series").

LANG, P.

1986 "Sacred Authority in Igbo Society", Archives de sciences sociales des religions 68: 73-90.

LEACH, E. (ed.)

1967 The Structural Study of Myth and Totemism (London: Tavistock Publications).

LeONARD, A. G.

1898 "Notes of a Journey to Bende", Journal of the Manchester Geographical Society XIV (2): 190.

Levi-Strauss, C.

1963 Totemism (Boston: Bacon Press).

MeEK, C. K.

1937 Law and Authority in a Nigerian Tribe (New York: Oxford University Press). 
Mojekwu, C. J.

1984 History of Umuchu, Final year student project, Department of History (Nsukka: University of Nigeria).

ORIJI, J. N.

1972 "Sacred Authority in Ibgo Society", Archives de sciences sociales des religions 68: 73-92.

1994 Traditions of Igbo Origin (New York: Peter Lang).

1998 Ngwa History: A Study of Social and Economic Developments in Igbo Mini States in Time Perspective (New York: Peter Lang).

OTTENBERG, S.

1958 "Ibo Oracles and Intergroup Relations", Southwestern Journal of Anthropology 24 (3): 295-314.

SCHNEIDER, A.

1998 "A Career Studying the Amistad Rebellion", The Chronicle of Higher Education, Jan. 9: A 12.

SteVEnson, R.

1968 Population and Political Systems in Tropical Africa (New York: Columbia University Press).

UKA, N.

1986 "A Note on the Abam Warriors of Igboland", Journal of African Studies 1 (2): $76-82$.

UKAegBu, E.

1974 History of Igbere (Aba: Span Press).

\section{ABSTRACT}

This paper examines the traditional cosmology of the Igbo of southeastern Nigeria to better understand the changes it underwent during the Trans-Atlantic slave trade. It argues that by then, the Aro and their Abam warriors, displaced many communities leading to the emergence of new place-names, totems and taboos. The concluding section uses the Igbo example to evaluate existing theories on totems and taboos, raising methodological issues that may enrich the study of African history and culture.

\section{RÉSUMÉ}

Transformations dans la cosmologie igbo pendant l'esclavage : une étude des genèses des noms de lieu, des totems et tabous. - Cet article étudie la cosmologie traditionnelle des Igbo dans le Sud-Est nigérien afin de mieux comprendre les changements qu'elle a subis pendant la traite d'esclaves transatlantique. Il soutient que les Aro et 
leurs guerriers abam ont déplacé beaucoup de communautés, ce qui a permis l'émergence de nouveaux noms de lieux, de totems et de tabous. La conclusion s'appuie sur l'exemple igbo pour évaluer des théories existantes sur les totems et les tabous, soulevant des questions méthodologiques pouvant enrichir l'étude historique africaine et sa culture.

Keywords/Mots-clés: Nigeria, Abam, Aro, Avosi, Ekpe society, Igbo, Nnewi, Okonko, cosmology, council of Elders (Amala), tabboos, totems/Nigeria, Abam, Aro, Avosi, société ekpe, Igbo, Nnewi, Okonko, cosmologie, conseil d'aînés (Amala), tabous, totems. 